\title{
PENGARUH WAKTU DAN SUHU TERHADAP PROSES PENGERINGAN BAWANG MERAH MENGGUNAKAN TRAY DRYER
}

\author{
Rintis Manfaati ${ }^{1, *}$, Hibah Baskoro ${ }^{1}$, Muhammad Muhlis Rifai ${ }^{1}$ \\ ${ }^{1}$ Jurusan Teknik Kimia, Politeknik Negeri Bandung \\ Jln. Gegerkalong Hilir, Ds. Ciwaruga, Bandung 40012 \\ *E-mail: rintismanfaati@gmail.com
}

\begin{abstract}
ABSTRAK
Peningkatan produksi bawang merah akan membuat stok melimpah dan harga bawang merah akan turun. Produk olahan bawang merah bertujuan untuk memperpanjang daya simpan dan meningkatkan nilai tambah. Salah satu metoda pengolahan dan pengawetan makanan adalah melalui pengeringan. Tujuan dari penelitian ini adalah untuk mengetahui suhu dan waktu pengeringan optimum serta laju pengeringan bawang merah menggunakan Tray dryer. Pada penelitian ini suhu pengeringan divariasikan pada range $50-70^{\circ} \mathrm{C}$, waktu pengeringan pada range 4-8 jam dan laju udara pengeringan $2,0 \mathrm{~m} / \mathrm{s}$. Analisis yang dilakukan terhadap produk adalah nilai kadar air menggunakan metode Gravimetri, kadar abu menggunakan metode pengabuan langsung/kering, dan kadar protein menggunakan metode Kjehdahl. Hasil penelitian menunjukkan bahwa suhu optimum pengeringan bawang merah menggunakan Tray dryer adalah $70^{\circ} \mathrm{C}$ dan waktu optimum pengeringan adalah 7 jam. Produk pengeringan memiliki nilai kadar air sebesar 4\%, kadar abu 3,95\%, dan kadar protein 2,3\%.
\end{abstract}

Kata kunci: Bawang merah, pengeringan, suhu, tray dryer, waktu

\begin{abstract}
An increase in onion production will create an abundant stock and price reduction. Onion products are processed to extend its shelf life and increase added value. One method of processing and preserving food is through drying. The purpose of this study was to determine the optimum temperature and drying time and the drying rate of red onion using Tray dryer. In this study the drying temperature was varied in the range of $50-70^{\circ} \mathrm{C}$, the drying time was in the range of 4-8 hours and the drying air rate was $2.0 \mathrm{~m} / \mathrm{s}$. Analysis of the product is the value of water content using the Gravimetry method, ash content using the direct ashes method, and protein content using the Kjehdahl method. The results showed that the optimum temperature of red onion drying using Tray dryer was $70^{\circ} \mathrm{C}$ and the optimum drying time was 7 hours. The drying product has a moisture content of $4 \%$, ash content of $3.95 \%$, and protein content of $2.3 \%$.
\end{abstract}

Keywords: Red onion, drying, temperature, tray dryer, time

\section{PENDAHULUAN}

Bawang merah (Allium ascalonicum L.) merupakan salah satu komoditas pertanian yang penting. Produksi bawang merah di Indonesia pada tahun 2016 adalah sebesar 1.446 .860 ton meningkat $17,71 \%$ dibanding tahun 2015 sebesar
1.229.184 ton (Badan Pusat Statistik (BPS), 2017). Produk olahan bawang merah yang bertujuan untuk memperpanjang daya simpan, meningkatkan nilai tambah, dan menganekaragamkan produk adalah bawang goreng, tepung bawang merah, kerupuk bawang merah dan pasta bawang merah. 
Salah satu metoda pengolahan dan pengawetan makanan adalah pengeringan. Proses pengeringan merupakan salah satu penanganan bahan pangan untuk meningkatkan mutu dan memperpanjang masa simpan bahan pangan. Pada penelitian ini metode tray drying dipilih karena memiliki kelebihan untuk proses pengeringan, yaitu penggunaan udara panas yang diharapkan membuat proses pengeringannya menjadi lebih cepat dan efektif.

Menurut Rostiati dkk (2013) bawang merah varietas lokal palu yang di goreng memiliki rentang kadar air sekitar 1,40\%-1,78\% bergantung dengan lokasi penanaman. Dalam penelitian Astuti (2008), dilakukan penelitian pengeringan bawang merah yang diiris tipis membujur dengan ketebalan 2-3 $\mathrm{mm}$ dan diletakkan dalam wadah alumunium foil dengan berat masingmasing 50g dengan tekanan atmosferik serta perlakuan suhu pada temperatur $50^{\circ} \mathrm{C}, \quad 60^{\circ} \mathrm{C}, \quad 70^{\circ} \mathrm{C}$ didapatkan hasil bahwa semakin tinggi suhu pengeringan, makin rendah kadar air karena pori-pori bahan lebih terbuka serta kepadatan udara lebih longgar sehinga memudahkan air menguap dari bahan. Pengeringan bawang merah iris menggunakan tunnel dehydrator dengan suhu pengering $40^{\circ} \mathrm{C}, 50^{\circ} \mathrm{C}, 60^{\circ} \mathrm{C}$ dan bobot sampel $300 \mathrm{~g}, 400 \mathrm{~g}, 500 \mathrm{~g}$ serta laju alir udara pengering sebesar 0,0933 m3/detik dilakukan pada kadar air awal bawang merah $\pm 80 \%$ dapat menghasilkan kadar air dibawah 10\% selama kurang dari 10 jam (Ummah, $\mathrm{N}$ dkk., 2016). Menurut penelitian yang dilakukan Balai Besar Penelitian dan Pengembangan Pasca Panen Pertanian (2018), bawang merah iris yang di keringkan menggunakan alat tunnel dryer dengan suhu $50^{\circ} \mathrm{C}$ dan waktu 10 jam memiliki kadar air 10,45\%; kadar abu 2,67\%; lemak 0,56\%; protein $15,12 \%$; dan karbohidrat $71,18 \%$

Setiap bahan padat yang dikeringkan memiliki karakteristik pengeringan yang berbeda-beda. Karakteristik ini dapat direpresentasikan dengan kurva laju pengeringan. Kurva tersebut dapat menunjukkan kadar air dalam bahan (bawang merah), laju pengeringan, dan waktu pengeringan sehingga dapat mengetahui keefektifan waktu proses untuk memperoleh produk yang sesuai. Proses pengeringan memiliki beberapa variabel yang dapat mempengaruhi kualitas produk yang dihasilkan contohnya adalah suhu dan waktu. Semakin tinggi suhu pengeringan, maka semakin cepat laju pengeringan yang terjadi dan dapat merusak produk karena lapisan luarnya terlalu cepat kering sedangkan bagian dalamnya masih basah.

Menurut McCabe (2002), Pengeringan (drying) artinya mengurangi sejumlah air atau cairan dari bahan padat, sehingga sisa air atau cairan dalam bahan padat tersebut mempunyai kandungan yang rendah dan dapat diterima. Pengeringan biasanya merupakan langkah terakhir dalam serangkaian atau operasi, dan produk dari pengering siap untuk pengemasan akhir. Bahan yang dikeringkan dapat berupa serpihan, butiran, kristal, bubuk, atau lembaran yang mungkin memiliki sifat yang sangat berbeda.

Proses pengeringan melibatkan dua proses perpindahan yaitu proses perpindahan panas dan proses perpindahan massa. Proses perpindahan panas terjadi dari udara pengering ke bahan yang akan dikeringkan, sedangkan perpindahan massa terjadi dalam dua tahap. Tahap pertama terjadi pada kandungan air yang terdapat didalam bahan ke permukaan bahan (proses difusi) selanjutnya tahap kedua terjadi pada proses peguapan air 
dari permukaan bahan ke udara menjadi uap air.

Proses pengeringan dapat diklasifikasikan menjadi pengeringan secara batch dimana bahan dimasukkan ke alat pengering dan dikeringkan dalam satu periode waktu, dan pengeringan secara kontinyu dimana bahan secara kontinyu dimasukkan ke dalam alat pengeringan dan bahan kering dikeluarkan secara kontinyu (Geankoplis, 1993).

Proses pengeringan juga dapat dibedakan berdasarkan media pemanasnya yaitu pengeringan adiabatik dimana media pemanas berkontak langsung dengan bahan yang dikeringkan, pengeringan non adiabatik dimana media pemanas tida berkontak langsung dengan bahan yang dikeringkan, dan pengeringan kombinasi yang menggabungkan antara adiabatik dan non adiabatik.

Salah satu alat pengeringan yang sering digunakan adalah tray dryer. Alat ini terdiri atas beberapa komponen utama yaitu nampan (tray), pemanas (heater), timbangan, dan blower. Proses pengeringan menggunakan tray dryer termasuk ke dalam jenis pengeringan langsung, dimana media pengering (udara panas) berkontak langsung dengan bahan yang akan dikeringkan.

Bahan yang akan dikeringkan menggunakan tray dryer harus berbentuk lembaran yang dihamparkan di atas tray. Proses pengeringan dimulai saat pemanas menyala dan panas yang dihasilkan mengalir melaui udara melintasi permukaan padatan dengan bantuan blower.

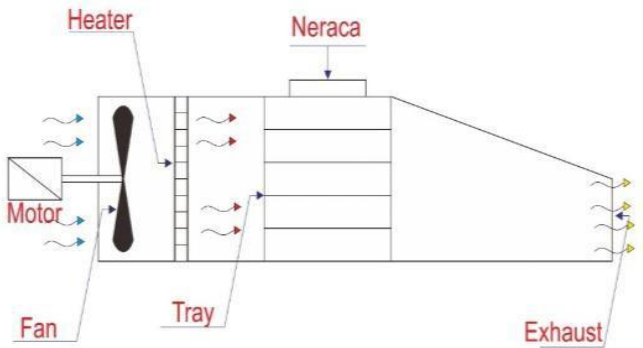

Gambar 1. Bagian-bagian dalam Tray dryer

Udara panas yang mengalir ini kondisinya belum jenuh dan kemudian ketika bersinggungan dengan padatan maka udara melepaskan sebagian panasnya sehingga terjadi proses penguapan air dari bahan yang akan menyebabkan udara mencapai kondisi jenuh. Jumlah air yang teruapkan dapat ditentukan dengan cara menghitung selisih massa padatan sebelum pengeringan dengan setelah pengeringan.

Kandungan air kesetimbangan untuk setiap bahan berbeda bergantung pada jenis bahan dan kelembaban relatif udara pengering. Data kesetimbangan biasanya diberikan sebagai hubungan antara kelembaban relatif udara dan zat cair yang terkandung dalam bahan padat (massa zat cair per massa padatan kering).

Menurut McCabe (2002), Bila suatu padatan basah dikontakkan dengan udara yang memiliki kelembaban yang lebih rendah dibanding padatan basah, maka padatan tersebut akan melepaskan sebagian dari kebasahannya dan mengering sampai seimbang dengan udara. Bila udara lebih lembab dibanding padatan basah maka padatan akan menyerap kebasahan dari udara hingga mencapai kesetimbangan. Kandungan air bebas merupakan selisih antara kandungan air total dalam bahan padat dengan kandungan air kesetimbangan. 
Penelitian ini akan menentukan suhu dan waktu optimum pengeringan dan laju pengeringan bawang merah menggunakan Tray dryer. Hasil penelitian ini digunakan untuk mendapatkan produk bawah merah kering yang memiliki kualitas terbaik sesuai dengan kebutuhan pasar.

\section{METODE}

Sebelum proses pengeringan, dilakukan pre-treatment bahan berupa pengupasan dan pengirisan bawang merah jenis Bima dengan ketebalan $\pm 1-2$ mm lalau bawang merah yang telah diiris disusun dengan luas permukaan pengeringan $20 \times 20 \mathrm{~mm}$ dalam tray berlubang. Laju alir udara pengering = $2,0 \mathrm{~m} / \mathrm{s}$. Pengambilan data berupa berat bawang merah dilakukan setiap 10 menit, sedangkan yang divariasikan adalah waktu dan temperatur pengeringan yaitu pada range $50-70^{\circ} \mathrm{C}$ dan 4-8 jam

Alat yang digunakan adalah Tray dryer merk Electronica Veneta yang dilengkapi pemanas berdaya 2,7 $\mathrm{kW}$, tray, termometer bola basah dan bola kering, cawan pijar, stop-watch, oven, furnace, tang penjepit, neraca analitik, desikator, perajang bawang merah (slicer), dan wadah kedap udara.

\section{Analisis Kadar Air}

Metode analisis kadar air menggunakan metode gravimetri. Analisis kadar air dilakukan dengan menguapkan air yang terdapat dalam bahan menggunakan oven dengan suhu $105^{\circ} \mathrm{C}$ selama 3 jam sehingga seluruh air yang terdapat dalam bahan menguap yang ditandai dengan penyusutan berat bahan sampai tidak berubah lagi.

\section{Analisis Kadar Abu}

Metode analisis kadar abu menggunakan metode pengabuan langsung/kering. Analisis kadar abu dilakukan dengan mengoksidasikan semua zat organik pada suhu yang tinggi sekitar $550^{\circ} \mathrm{C}$ selama 2-8 jam bergantung bahan yang diabukan.

Pengabuan dianggap selesai apabila diperoleh sisa pengabuan berwarna putih abu-abu dan memiliki berat konstan.

\section{Analisis Kadar Protein}

Metode analisis kadar protein menggunakan metode Kjehdahl. Kadar protein yang ditentukan menggunakan cara kjehdahl disebut sebagai protein kasar (crude protein) karena terikut senyawa $\mathrm{N}$ bukan protein. Prinsip kerja metode Kjeldahl adalah protein dan komponen organik dalam sampel didestruksi dengan menggunakan asam sulfat dan katalis. Hasil destruksi dinetralkan dengan menggunakan larutan alkali. Selanjutnya ion- ion borat yang terbentuk dititrasi dengan larutan $\mathrm{HCl}$.

\section{HASIL DAN PEMBAHASAN}

Pada penelitian ini bawang merah disimpan dalam tampah bambu pada suhu ruang dengan keadaan terbuka. Bawang merah sebagai bahan awal tidak bisa di jadikan sebagai variabel tetap karena hanya mempunyai masa simpan selama \pm 2 minggu, maka varietas bawang merah yang dipakai tidak bisa dipastikan seragam karena dibeli pada waktu yang berbeda, sehingga variabel tetap yang bisa dipertahankan adalah ketebalan irisan bawang merah.

\section{Suhu Optimum Pengeringan}

Penentuan suhu optimum pada proses pengeringan bawang merah ini bertujuan untuk mengetahui pada suhu berapa bawang merah memiliki nilai kadar air paling rendah $(<10 \%)$ dengan waktu yang ditetapkan selama 6 jam. Kadar air merupakan salah satu sifat kimia dari bahan yang menunjukkan banyaknya air yang terkandung di dalam 
bahan pangan. Proses pengeringan bertujuan untuk mengurangi kadar air bahan sehingga memperpanjang masa simpan produk dan juga mempengaruhi mutu produk. Kadar air bebas dalam bahan mendekati nilai nol akan menghambat pertumbuhan mikroorganisme, aktivitas enzim, dan reaksi kimia sehingga umur simpan bahan pangan akan lebih panjang.

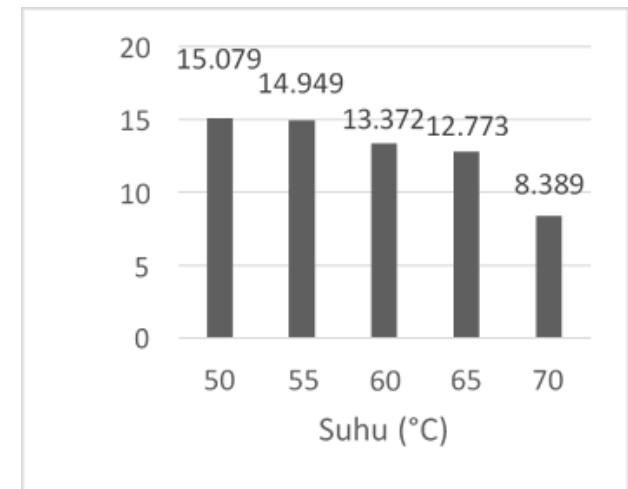

Gambar 2. Kurva Pengaruh Suhu terhadap Kadar Air

Gambar 2 menunjukan bahwa semakin besar suhu yang digunakan dalam proses pengeringan maka semakin rendah kadar air yang dihasilkan. Hal ini menunjukan bahwa kadar air terendah pada suhu $70^{\circ} \mathrm{C}$, semakin tinggi suhu yang digunakan memberikan pengaruh yang sangat besar terhadap kecepatan perpindahan air. Semakin tinggi suhu pengeringan maka semakin cepat terjadi penguapan.

Laju pengeringan berdasarkan Gambar 3 menunjukan semakin besar suhu pengeringan maka semakin cepat laju pengeringan yang terjadi. Hal tersebut disebabkan oleh semakin tingginya suhu udara pengering sehingga semakin tinggi energi panas yang dibawa udara sehingga semakin banyak jumlah massa cairan yang diuapkan dari permukaan bahan. Kenaikan suhu pengering akan menaikkan suhu bahan dan menyebabkan tekanan uap air di dalam bahan lebih tinggi dibandingkan tekanan uap air di udara, sehingga terjadi perpindahan uap air dari bahan ke udara.

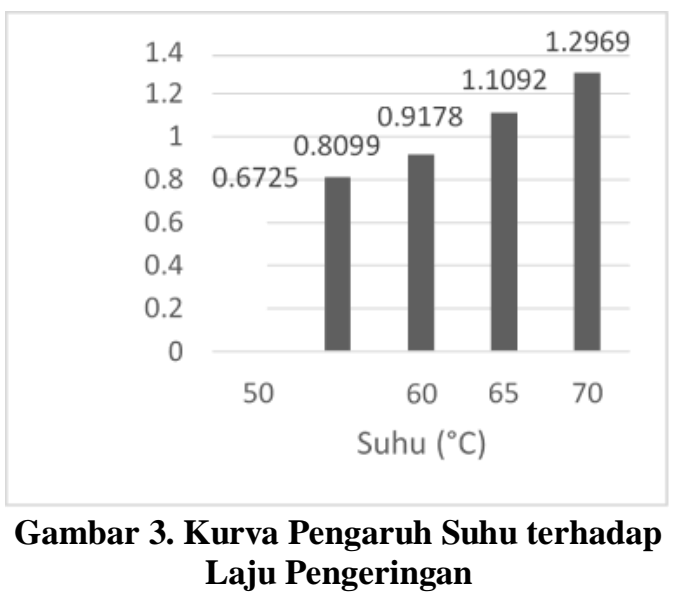

Abu merupakan residu anorganik dari hasil pembakaran atau hasil oksidasi komponen organik bahan pangan. Kadar abu ada hubungannya dengan kandungan mineral suatu bahan. Penentuan kadar abu total dapat digunakan untuk menentukan baik atau tidaknya suatu pengolahan, mengetahui jenis bahanbahan yang digunakan, dan menentukan parameter nilai gizi suatu bahan makanan. Kandungan abu dapat digunakan untuk memperkirakan kandungan dan keaslian bahan yang digunakan. Berdasarkan hasil penelitian yang ditunjukan pada Gambar 4, kadar abu menunjukan nilai yang relatif sama. Perbedaan nilai kadar abu dikarenakan pengaruh dari kondisi bahan awal sebelum pengeringan yang berbedabeda. Berdasarkan nilai kadar air, kadar abu, dan laju pengeringan maka suhu $70^{\circ} \mathrm{C}$ merupakan suhu optimum pada proses pengeringan bawang merah menggunakan alat Tray dryer. 


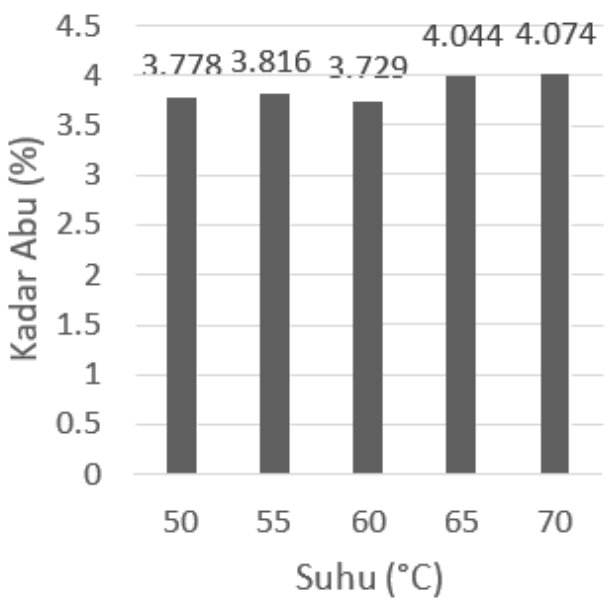

Gambar 4. Kurva Pengaruh Suhu Terhadap Kadar Abu

\section{Waktu Optimum Pengeringan}

Penentuan waktu optimum pada proses pengeringan bawang merah ini bertujuan untuk mengetahui pada suhu optimum pengeringan $70^{\circ} \mathrm{C}$ membutuhkan waktu berapa lama untuk menghasilkan produk bawang merah iris kering yang mempunyai nilai kadar air paling rendah.

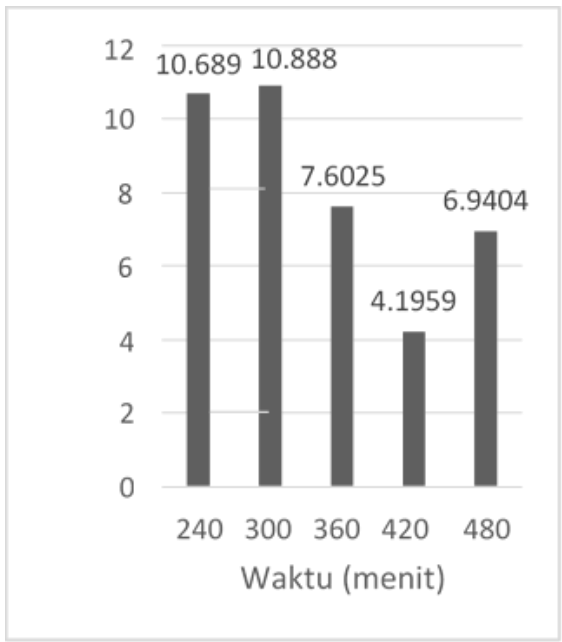

Gambar 5. Kurva Pengaruh Waktu Terhadap Kadar Air Pada Suhu $7^{\circ} \mathrm{C}$

Produk pengeringan pada suhu $70^{\circ} \mathrm{C}$ dengan waktu 7 jam memiliki kadar air sebesar 4,2\% dan kadar abu $3,96 \%$, hal ini menunjukan hasil produk yang lebih baik dibandingkan dengan penelitian yang telah dilakukan oleh
(Balai Besar Penelitian dan Pengembangan Pasca Panen, 2018), dimana bawang merah iris yang dikeringkan menggunakan alat tunnel dryer dengan suhu $50^{\circ} \mathrm{C}$ dan waktu 10 jam memiliki kadar air 10,45\% dan kadar abu 2,67\% . Uji protein dilakukan untuk mengetahui apakah pada proses pengeringan dengan kondisi operasi yang telah ditetapkan terjadi proses denaturasi protein, proses denaturasi protein mengindikasikan terjadinya perubahan struktur dari minyak atsiri karena memiliki titik perubahan struktur pada suhu yang relatif sama. Pengujian protein dilakukan pada sampel dengan suhu $70^{\circ} \mathrm{C}$ selama 7 jam dan $65^{\circ} \mathrm{C}$ selama 6 jam dengan kadar protein sebesar 2,3\% dan 2,12\%. Hal ini menunjukkan bahwa proses pengeringan hingga $70^{\circ} \mathrm{C}$ tidak mempengaruhi nilai kadar protein bawang merah, adapun selisih nilai kadar protein tiap sampel disebabkan oleh kondisi/varietas bawang yang berbeda.

\section{SIMPULAN}

Dari hasil penelitian dapat disimpulkan hal-hal berikut:

a. Suhu optimum untuk pengeringan bawang merah menggunakan alat tray dryer adalah $70^{\circ} \mathrm{C}$ dengan waktu optimum selama 7 jam yang menghasilkan produk dengan kadar air 4\%, kadar abu 3,95\%, dan kadar protein 2,3\%.

b. Kurva laju pengeringan bawang merah yang diperoleh berbeda-beda bergantung suhu pengeringannya dan kurva pengeringan yang baik diperoleh pada suhu 60, 65 dan $70^{\circ} \mathrm{C}$.

Penelitian ini dapat diterapkan dengan beberapa saran agar hasil yang diperoleh lebih baik yaitu sebagai berikut. 
a. Kelembaban udara harus dijaga tetap kering agar proses pengeringan dapat berlangsung maksimal.

b. Bawang merah yang digunakan harus segar atau maksimal berumur satu minggu setelah masa penyimpanan agar kondisi operasi yang digunakan sesuai.

\section{UCAPAN TERIMA KASIH}

Penelitian ini didanai oleh DIPA Polban dengan No. Perjanjian Pelaksanaan Penelitian Mandiri Nomor 438.31/PL1.R7/LT/2019

\section{DAFTAR RUJUKAN}

Alamsyah, R., G. Pohan, dan A. S. Herman. 2008. Kajian Penerapan Alat Pengering Bawang Merah di Sentra Produksi Brebes - Jawa Tengah. Jurnal Riset Industri, (2).

Astuti, S. M. 2008. Teknik Pengeringan Bawang Merah dengan Cara Perlakuan Suhu dan Tekanan Vakum. Buletin Teknik Pertanian, (13).

Badan Pusat Statistik (BPS). 2017. Statistik Tanaman Sayuran dan Buah-buahan Semusim Indonesia (online). http://www.bps.go.id/, diakses Februari 2019.

Balai Besar Penelitian dan Pengembangan Pasca Panen Pertanian. 2018. (online). http://www.pasca panen.litbang pertanian.go.id/, diakses Februari 2019.

Geankoplis, C.J. 1993. Transport Process and Unit Operations $\left(3^{\text {rd }}\right.$ Edition). Prentice-Hall International, Inc.
Henderson, S. M., dan R. L. Perry. 1955. Agricutural Process Engineering. New York; John Wiley \& Sons, Inc.

Mc.Cabe, Warren L. 2002. Unit Operation of Chemical Engineering $\quad\left(4^{\text {th }} \quad\right.$ Edition). Singapura; McGraw Hill International Book Co.

Nugraha, S., R. S. Adiandri, dan Yulianingsih. 2011. Pelayuan dan Pengeringan Bawang Merah Menggunakan Instore Drying untuk Mempertahankan Mutu dan Mengurangi Tingkat Kerusakan. Bogor; Balai Besar Penelitian dan Pengembangan Pascapanen Pertanian.

Rostiati, Alam, N., dan Muhardi. 2014. Sifat Fisik-Kimia dan Organoleptik Bawang Goreng Palu Pada Berbagai Frekuensi Pemakaian Minyak Goreng. Jurnal Fakultas Pertanian Universitas Tadulako.

Traub, Daren A. 2002. The Dryng Curve Part 1 (online). https://www.processheating.com/ articles/86586-the-dryng- curvepart-1, diakses 12 Juli 2019.

Ummah, N., A. P. Purwanto, dan A. Suryani. 2016. Penentuan Konstanta Laju Pengeringan Bawang Merah (Allium ascalonicum L.) Iris Menggunakan Tunel Dehydrator. Bogor: Institut Pertanian Bogor, Fakultas Teknologi Pertanian.

United States Departement of Agriculture USDA. 2012. Plant Database for Standar Reference (online), https://plants.sc.egov. usda.gov/java/, diakses Januari 2019. 